\title{
DEBRET E MACHADO: VOZES E IMAGENS DA ESCRAVIDÃO NO BRASIL
}

\author{
Gilson Ramos Lopes Neto ${ }^{1}$ \\ João Luis Pereira Ourique ${ }^{2}$
}

Resumo: A escravidão institucionalizada no Brasil deu seus últimos suspiros apenas no fim do século XIX. Enquanto a Europa vivenciava o Positivismo comteano durante o auge vanguardista e promissor da Revolução Industrial, as barbáries vivas do sistema escravagista brasileiro ecoavam não apenas na literatura, mas também na pintura. Este estudo aborda o trabalho de dois remarcáveis artistas dessa época que se serviram da arte para denunciar, de forma sutil e ao mesmo tempo incisiva, a banalização das práticas escravagistas da época: o desenhista francês Jean-Baptiste Debret (1768-1848) e o escritor carioca Machado de Assis (1839-1908). Para fundamentar a discussão, será realizada uma análise epistemológico-comparativa entre 3 litografias de Debret e o conto "Pai contra mãe", de Machado de Assis, considerando os subsídios teóricos que entendem a relação das imagens como narrativas a partir dos escritos de Alberto Manguel e da perspectiva da Dialética Negativa de Theodor Adorno.

Palavras-chave: Escravidão; Leitura; Imagens; Narrativas; Dialética Negativa.

Résumé: L'esclavage institutionnalisé au Brésil rend ses derniers soupirs seulement à la fin du XIXème siècle. Pendant que l'Europe vivait le Positivisme d'Auguste Comte durant l'apogée d'avant-garde et prometteur de la Révolution Industrielle, la barbarie toujours présente du système esclavagiste brésilien avait un écho pas seulement dans la littérature, mais aussi dans la peinture. Cette étude aborde le travail de deux remarquables artistes de cette époque qui se sont servis de l'art pour dénoncer, sous forme subtile et en même temps incisive, la banalisation des pratiques esclavagistes de l'époque : le dessinateur français Jean -Baptiste Debret (1768-1848) et l'écrivain de Rio Machado de Assis (1839-1908). Pour soutenir la discussion, une analyse épistémologique comparative sera réalisée entre 3 lithographies de Debret et le conte « Père contre mère " ("Pai contra mãe") de Machado de Assis, tenant compte des apports théoriques qui prennent en considération la relation des images en tant que narrations à partir des écrits d'Alberto Manguel et de la perspective de la Dialectique Négative de Theodor Adorno.

Mots-clés: Esclavage ; Lecture ; Images ; Narrations ; Dialectique Négative.

1 Mestre em Letras pelo Programa de Pós-Graduação em Letras (PPGL) da Universidade Federal de Pelotas (UFPel/RS-Brasil).gilson.lopes@teachers.org.

2 Professor Adjunto da Universidade Federal de Pelotas (UFPel/RS-Brasil), Doutor em Estudos Literários. jlourique@ yahoo.com.br 


\section{RETRATOS DA ESCRAVIDÃO NO BRASIL}

A temática da escravidão, externada recorrentemente nas artes como uma denúncia, é aqui abordada a partir de uma discussão epistemológico-comparativa entre o conto Pai contra mãe, de Machado de Assis, publicado em 1906, e três pinturas de Jean-Baptiste Debret: "Feitores castigando negros"3 (originalmente Feitors Corrigeant des Nègres), "Sapataria" (originalmente Boutique de Cordonnier) e "O Jantar" (originalmente Le Diner). Essas quatro obras denunciam a prática desumana do escravismo brasileiro do século XIX e, no presente trabalho, sustentam o pressuposto de que as narrativas não são eternizadas somente através dos textos escritos, mas igualmente por imagens, conforme Alberto Manguel (2001). Segundo o autor, imagens consistem num sistema autossuficiente de signos e regras, traduzindo-se como narrativas.

Em paralelo a uma reflexão teórica relacionada ao compromisso não apenas artístico, mas também político-social de ambos os autores, este estudo põe em perspectiva a importância exponencial dessa leitura crítica com o intuito de contribuir com a formação histórica e cultural da sociedade brasileira.

Para tanto, nosso percurso de leitura parte do reconhecimento de que as práticas escravagistas estão entranhadas nos 5 séculos de desenvolvimento agrário e industrial nas Américas. Lamentavelmente, o Brasil se destaca nesse contexto, tendo igualmente legalizado o escravismo como seu principal modo de produção econômica e também por ter sido o último país neste continente a abolir as barbáries desta prática institucionalizada. Nesse período, milhões de indivíduos negros foram sequestrados de sua terra natal e de sua família e transportados de forma desumana em embarcações insalubres e em condições deploráveis, vindo a se constituir na grande maioria na população brasileira. Indivíduos que não tiveram o reconhecimento de suas origens à época e nem de sua cidadania ao longo dos séculos, tendo apagados os registros de sua história e sem direito a novas narrativas - tanto de si quanto para seus descendentes.

As Artes, em suas diversas e plurais manifestações, eternizaram valiosos registros dessa prática impiedosa num país tropical abençoado por Deus e bonito por natureza. Mesmo tendo o escravismo ${ }^{6}$ como pano de fundo, seja sincrônica ou diacronicamente observada, amores se fizeram florescer em inúmeras obras. Em outras, o compromisso com a denúncia

\footnotetext{
3 Disponível em: <https://digital.bbm.usp.br/handle/bbm/3408>. Acesso em: 04 Maio 2019 (DEBRET, 1835b, p. 84). 4 Disponível em: <https://digital.bbm.usp.br/handle/bbm/3755>. Acesso em: 04 Maio 2019 (DEBRET, 1835b, p. 92). 5 Disponível em: <https://digital.bbm.usp.br/handle/bbm/3725>. Acesso em: 04 Maio. 2019 (DEBRET, 1835b, p. 42). 6 Em alguns momentos do trabalho, utilizamos os termos escravismo e escravagismo não apenas para citar a questão institucionalizada da escravidão, mas para enfatizar o caráter desumano das práticas no contexto brasileiro. Estes vocábulos, segundo dicio.com.br, são apresentados como sinônimos recorrentes, enquanto que escravidão abrange outros campos lexicais por metonímia, tais como amor, vícios e hábitos.
} 
falou mais alto, como observado nas 3 litografias de Jean-Baptiste Debret $(1768-1848)^{7}$ todas publicadas em 1835; e o conto "Pai contra mãe" do escritor carioca Machado de Assis $(1839-1908)^{8}$, publicado em 1906. Desde o século XIX, o Brasil foi bastante retratado de forma escrita aos olhos de cientistas (como Auguste Saint-Hilaire, botânico, no início do século XIX) e igualmente por desenhistas, sendo Debret e Johann Moritz Rugendas dois dos maiores expoentes nesse período.

Propõe-se aqui, através da teoria da leitura de imagens com base nas reflexões de Alberto Manguel (2001), um estudo comparativo do conto machadiano com as litografias debretianas.

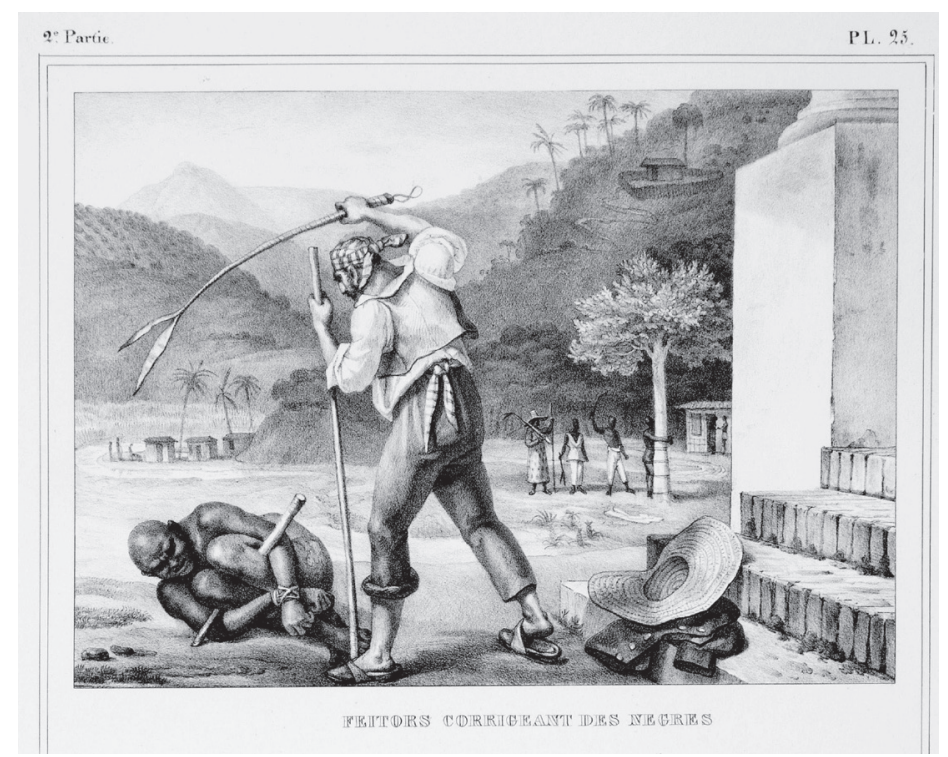

Imagem 1: Litografia “Feitores corrigindo negros" (DEBRET, 1835b, p. 84).

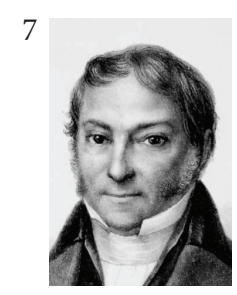

Jean-Baptiste Debret (1768-1848) nasceu e faleceu em Paris, França, onde frequentou a Academia de Belas Artes, tendo sido aluno de seu primo Jacques-Louis David, líder do neoclassicismo francês. Foi pintor, professor, desenhista, gravador, decorador e cenógrafo. Chegou ao Brasil em 1816 graças ao ingresso à Missão Artística Francesa, tendo permanecido no país até 1831. Além de promover o ensino artístico na cidade carioca, registrou, durante sua visita a várias cidades brasileiras, a fauna e a flora, assim como eventos e atividades culturais, políticas e econômicas. Publicou "Viagem Pitoresca e Histórica ao Brasil", obra dividida em 3 tomos. (ITAÚ CULTURAL, 2016) Fonte da imagem: Debret $(1834, \mathrm{~s} / \mathrm{p}$ )

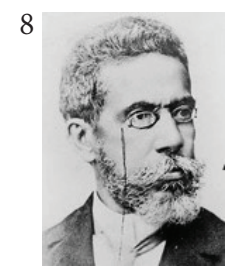

Joaquim Maria Machado de Assis (1839-1908) nasceu e faleceu no Rio de Janeiro. É fruto da união de um brasileiro com uma açoriana, então moradores do Morro do Livramento. Foi cronista, romancista, crítico literário e atuou igualmente na política. Teve sua primeira produção literária, o poema "Ela", publicada em 1855 aos 16 anos de idade. Atuou em jornais e revistas da então capital do Brasil, tendo recebido diversos prêmios e condecorações. Participou da inauguração da Academia Brasileira de Letras, da qual foi presidente por mais de uma década. Sua vasta produção literária e estilo crítico fizeram com que se tornasse um dos grandes ícones da literatura nacional. (MARINHO, s/a) Fonte da imagem: http://machado.mec.gov.br/\# 


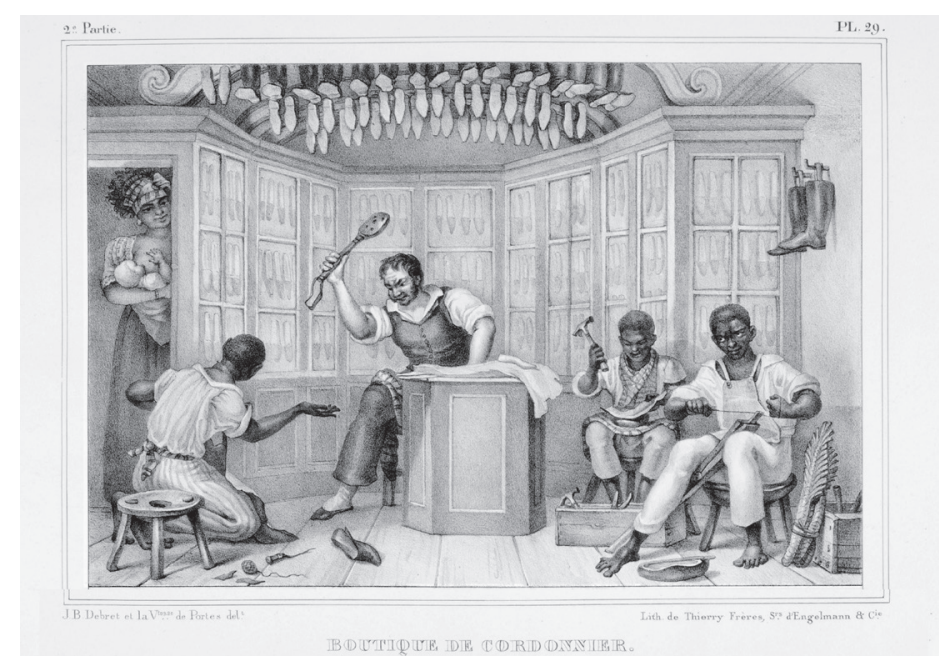

Imagem 2: Litografia “Sapataria” (DEBRET, 1835b, p. 92).

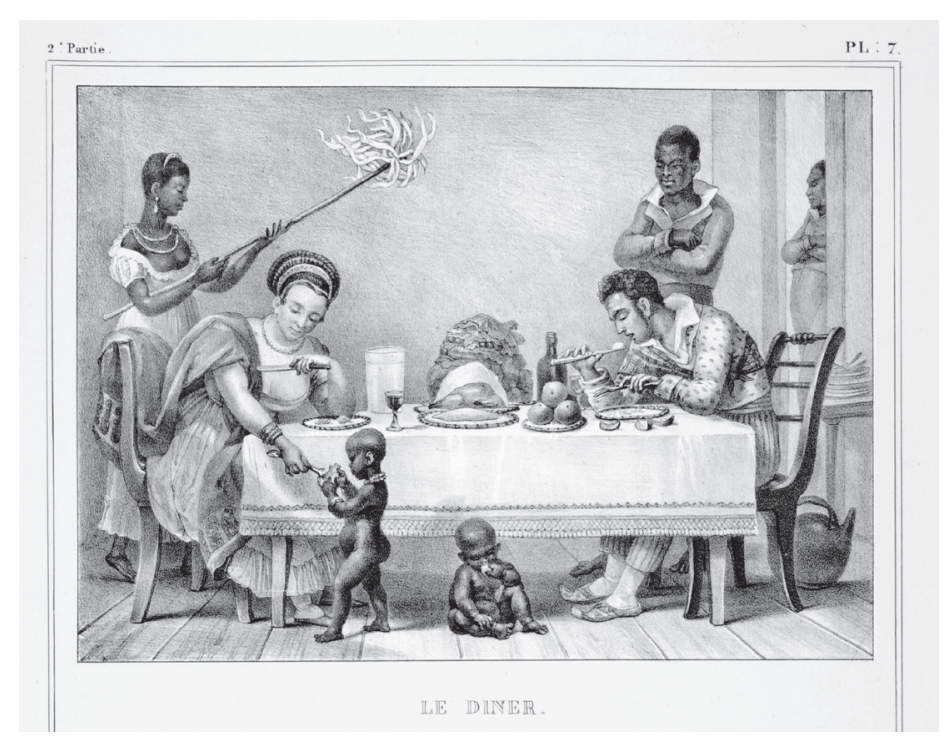

Imagem 3: Litografia “O Jantar” (DEBRET, 1835b, p. 42).

Como já mencionado, diferentes gêneros artísticos têm abordado o escravagismo no Brasil, porém, com um sentido de estranheza/distanciamento. O discurso do Senador Afonso Arinos na sessão solene comemorativa do Centenário da Abolição à Escravatura afirma que a prática escravagista no Brasil tem ecoado na Literatura Brasileira:

"A literatura menciona sempre escravos, desde o romantismo da 'Escrava Isaura, de Bernardo Guimarães, até os escravos domésticos ligados às famílias dos personagens, na primeira parte inicial da obra de Machado de Assis" (BRASIL, 2012, p. 21).

As cenas de barbáries escravagistas foram também vivenciadas por outros europeus no século XIX, dentre eles o viajante Auguste de Saint-Hilaire (1779-1859), professor de Botânica de origem francesa. As atrocidades retratadas pelo compatriota de Debret em suas cadernetas de viagem ao Brasil 
antecedem em poucos anos antes a chegada deste à Cidade Maravilhosa. Apesar de o escravismo ter sido abolido nas colônias francesas apenas em 27 de abril de 1848, o viajante aponta que, no inverno de 1820, a sua pior vivência nesse tema ocorreu em Pelotas às margens do Rio Pelotas. Segue o excerto estarrecedor de Saint-Hilaire sobre a "criatura mais infeliz" que tivera conhecido:

"RIO PELOTAS, 11 de setembro. - [...] Nas charqueadas os negros são tratados com muito rigor. O Sr. Chaves é considerado um dos charqueadores mais humanos, no entanto ele e sua mulher só falam a seus escravos com extrema severidade, e estes parecem tremer diante dos seus patrões. Há sempre na sala um negrinho de dez a doze anos, que permanece de pé, pronto a ir chamar os outros escravos, a oferecer um copo de água e a prestar pequenos serviços caseiros. Não conheço criatura mais infeliz do que esta criança. Não se assenta, nunca sorri, jamais se diverte, passa a vida tristemente apoiado à parede e é, freqüentemente, martirizado pelos filhos do patrão. Quando anoitece, o sono o domina, e quando não há ninguém na sala, põe-se de joelhos para poder dormir; não é esta casa a única onde há este desumano hábito de se ter sempre um negrinho perto de si para dele utilizar-se, quando necessário. (SAINT- HILAIRE, 2002, p. 119-120).

No campo jurídico, a Lei $\mathrm{n}^{\circ} 1.237$, de 24 de setembro de 1864, determina que os escravos pertencentes às propriedades agrícolas são considerados como objeto de hipoteca e de penhor (BRASIL, 2012, p. 214), relativamente semelhante ao que ocorria na Idade Média nas terras europeias sob domínio do Rei Carlos Magno (DIGNAT, 2018). As relações escravagistas de produção tendiam a ser vistas como a única forma para um país sobreviver. O Manifesto da Sociedade Brasileira contra a escravidão, publicado no Rio de Janeiro em 1880 e disponível na Biblioteca do Senado Federal registrada sob o $n^{\circ} 3338$, relata que "Aos olhos dos brasileiros tradicionais, o Brasil sem escravos sucumbiria logo[...]” (BRASIL, 2012, p. 622). Opondo-se a esse discurso proferido pelos defensores ferrenhos do sistema escravocrata, o Manifesto da Confederação Abolicionista do Rio de Janeiro, de 1883, aponta, detalhadamente em números e em períodos, que o lucro dependente da mão de obra escrava é uma ilusão: "Quanto à lavoura é dever do Parlamento convencê-la de que longe de cavar a sua ruina, a abolição da escravidão vem dar-lhe a maior pujança” (BRASIL, 2012, p. 688). Efetivamente, o fim oficial da escravidão fez melhorar o faturamento da atividade agrícola em vez de fracassar.

De acordo com a Enciclopédia Itaú Cultural (2016, s/n), "Debret confere à obra um caráter cívico e preocupa-se com a necessidade de criação de um imaginário político". Acrescenta que o artista se preocupa com a questão documental das cenas típicas de atividades e costumes do Rio de Janeiro, procurando traçar um painel social da cidade. Aponta ainda que Debret apresenta muitos aspectos relacionados ao trabalho escravo, ora acentuando o lado mais expansivo das relações sociais, ora expondo serviços extenuantes, como os de carregadores e trabalhadores das moendas. Nas telas de Debret, ainda segundo Itaú Cultural (2016), o trabalho diversificado dos negros de ganho, percorrendo espaços públicos cariocas, é bastante representado.

Segundo Antunes (2016), Debret teria tido seu primeiro contato com uma natureza de 
flora e fauna exuberantes em 1816, ano de sua chegada junto com os demais membros da Missão Artística da França ao Brasil. Esse estrangeiro se deparou com uma população rica em cores e sensualidades de gestos, repleto de escravos africanos, notoriamente contrastando com a cultura europeia. Efetivamente, esse cenário teria encantado Debret de imediato, tendo, consequentemente, refletido nas suas pinturas e litogravuras.

Essa miscigenação, vista de perto, teria assombrado esse pintor francês, pois passou a perceber as brutalidades da cultura escravagista institucionalizada. Antunes (2016) cita as considerações do historiador Rodrigo Naves, que menciona a dificuldade do pintor em transpor para o papel fielmente à sua formação neoclássica. A maior dificuldade apontada pelo historiador se refere à temerosa realidade brasileira, tanto na questão escravocrata juridicamente ainda autorizada no país, quanto também na instauração de uma monarquia em vez de uma república.

Debret, ainda segundo Antunes (2016), apresentava agilidade em produzir aquarelas com um colorido espontâneo, leve e harmonioso. Essa herança neoclássica adaptada ao que os seus olhos queriam retratar teria favorecido a representação do porte físico dos escravos com aspecto vulnerável e limitado. Pode-se, portanto, inferir que a submissão retratada não se resumiria exclusivamente a aspectos sócio-cultural-econômicos, mas a ingenuamente físicos.

As vestimentas retratadas por Debret, segundo Antunes (2016), apresentam forte ambiguidade. Em geral, são representadas de forma sobrepostas, soltas, meio esgarçadas e rudes. As roupas dos negros não mantêm vínculos com a tradição dos planejamentos de época. Os personagens de Debret portam tecidos que transmitem aos corpos sua falta de consistência. A sutileza do tom de cinza, presente na maioria das gravuras, transparece situações dúbias da sociedade, aproximando as figuras do seu ambiente por meio de uma espécie de liga que unifica as cenas. Quanto aos indígenas, Antunes (2016) afirma que eles são representados de forma idealizada, numa mistura de fantasia e de ciência: são figuras fortes e muitas vezes representadas em cenas heroicas.

Segundo Costa e Diener (2009), a representação do indivíduo negro por Debret apresenta uma postura ambivalente. Esses autores sugerem que haja contrastes em relação às representações de escravos observadas ao longo de sua obra. A influência da escola neoclássica apresentaria modos díspares de retratá-los, transparecendo quase que caricaturalmente o realismo brasileiro. São as escravas e os escravos representados, portanto, como indivíduos fortes e sensuais, quase que regularmente associado ao trabalho servil, nos eventos e nos encontros. Apontam, ainda, que o dilema debretiano reflete nas suas obras: a pretensão documental em conflito com a verossimilhança (ou o realismo). Dessa forma, torna-se difícil traçar um paralelo entre o engajamento militante sartriano e o engajamento adorniano artístico. Este, buscando formas de um corpo humano perfeito, ideal, mímese da estética greco-romana; aquele, testemunhando a anatomia dos escravos "in vivo et in loco".

É oportuno citar Manguel (2001) no que tange à fidelidade recorrente do artista com os estilos ou técnicas preponderantemente observadas em suas obras. O autor afirma que, segundo Malraux, Picasso ridicularizava um pintor francês, coincidentemente membro da família de Debret, o artista Jacques-Louis David. Trata-se de um dos principais representantes acadêmicos do estilo dito Neoclássico emergente no século XVIII. "A tela não tinha 
de retratar a emoção do pintor, mas o modelo fazendo os gestos convencionais de uma emoção". (MANGUEL, 2001, p. 206). Sendo Debret igualmente um representante da escola artística de David, observa-se que as telas daquele não exploravam cores tampouco propunham distorções nas representações dissonantes do Neoclassicismo. Demonstrou-se, assim, fidelidade das obras de Debret ao movimento artístico pictórico que imperava no século XVIII-XIX até poucas décadas antes do advento da fotografia. Mesmo com toda fidelidade à técnica, o conteúdo narrativo de teor escravagista presente em diversas imagens de Debret elaboradas no Novo Continente causou estranhamento - até mesmo indignação - a seus inúmeros críticos e observadores do Velho Continente. Essas cenas, portanto, demonstraram não ser mais toleradas na Europa, retratando brutalidades retrógradas desonrosas à sincronia da produção debretiana.

Os reflexos históricos a partir das pinturas de Debret também são percebidos na obra "Pai contra mãe", de Machado de Assis. O conto, narrado em terceira pessoa e cuja neutralidade é apenas aparente, se insere com o intuito de apontar o absurdo da condição do escravismo na sociedade brasileira.

Podemos afirmar, portanto, que Machado buscou denunciar, assim como Debret, as atrocidades e o imaginário conservador de uma sociedade problemática localizada na então capital do Brasil. Essas imagens presentes na narrativa e essas vozes mudas retratadas nas litografias possibilitam reiterar a afirmação de Manguel de que, "livros [...] são feitos de uma única página, dura e grossa” (2001, p. 19), pondo criticamente o imaginário coletivo em xeque sobre a pintura como uma expressão artística encerrada e completa. Propõe, então, que a imagem consistiria num sistema auto-suficiente de signos e regras, que ocasionaria uma tradução de imagens como uma narrativa. Essa leitura de textos imagísticos, por sua vez, está intrinsicamente ligada às aptidões e limitações do leitor. Sob esse prisma, o autor sugere:

\begin{abstract}
Vemos uma pintura como algo definido por seu contexto: podemos saber algo sobre o pintor e sobre o seu mundo; podemos ter alguma ideia das influências que moldaram sua visão; se tivermos consciência do anacronismo, podemos ter o cuidado de não traduzir essa visão pela nossa - mas, no fim, o que vemos não é nem a pintura em seu estado fixo, nem uma obra de arte aprisionada nas coordenadas estabelecidas pelo museu para nos guiar." (MANGUEL, 2001, p. 27).
\end{abstract}

Atribui ao ser humano uma alta capacidade de produzir linguagem e de abstrair, apesar da grande limitação perceptiva desse indivíduo. Afirma, ainda, que o homem está em constante movimento, redefinindo-se, (re)construindo-se e interagindo dinamicamente a todo o momento com os seus semelhantes e com o seu meio. Dessa forma, conclui que sons e rabiscos aglomeráveis não seriam os únicos recursos para representar a dita realidade, diferenciando um espectador de um leitor. Por conseguinte, Manguel (2001) destaca que imagens dão origem a histórias que oportunizam a origem de imagens.

Manguel sugere produtivos conceitos a vocábulos diversos. Por exemplo, conceitua conhecimento como mera recordação, novidade como mero esquecimento e imagens como 
um memento mor $i^{9}$ e, inclusive, como parte daquilo que somos. Acrescenta que imagens também suscitam interpretações novas e até mesmo originais. Os limites dessa apreensão de pinturas, segundo o autor, são impostos pela linguagem humana em sua pancronia de acordo com os arquétipos do seu meio (in)direto, acrescentando que "Somos essencialmente criaturas de imagens, de figuras." (MANGUEL, 2001, p. 21). Para o ensaísta em questão, as imagens são tão eficazes para informar quanto histórias e pensamento. Estes, por sua vez, dependem de imagens para se manifestar sob uma perspectiva aristotélica. Acrescenta que as percepções diretas são efetivamente das imagens, diferindo-se dos textos escritos. Manguel (2001) cita Aristóteles para evidenciar a importância da imagem mental: "a alma nunca pensa sem uma imagem mental" (MANGUEL, 2001, p. 21). A partir do exposto acima, torna-se relevante mencionar que a ciência da linguagem, a Linguística, estabeleceu-se com a teorização saussuriana da "imagem acústica", legitimando que um carimbo composto por sons carrega sentido contextualizado. Manguel (2001) afirma:

As imagens que formam nosso mundo são símbolos, sinais, mensagens e alegorias. Ou talvez sejam apenas presenças vazias que completamos com o nosso desejo, experiência, questionamento e remorso. Qualquer que seja o caso, as imagens, assim como as palavras, são a matéria de que somos feitos. (MANGUEL, 2001, p. 21)

Suas considerações sobre as histórias em quadrinhos oportunizam discutir a exigência que esse tipo de gênero literário oferece ao leitor a partir da leitura visual ou auditiva de uma narrativa. Tanto diegeses textuais quanto gibis, por exemplo, são apreendidas de forma linear, sequencial e temporal, assim como espacial.

A partir de uma visão conservadora enaltecedora da narrativa escrita, as palavras tendem a transpassar os limites da página, enquanto as imagens debilitar-se-iam inevitavelmente a uma tela no âmbito espacial. Em contrapartida, afirma o autor, a análise imanente à imagem não inibe a excelência da interpretação de elementos componentes do objeto observado, sem impedir uma leitura consistente, produtiva e cuidadosa. Acrescenta que o observador de uma pintura, de uma fotografia, de um desenho ou de uma escultura tem, como ponto de partida, a mera observação do objeto diante de seus olhos no qual atribui-se uma leitura temporal. Assim, esse íntimo contato entre o apreciador de arte com a obra oportuniza, unicamente a partir desse momento conforme o autor, a uma intensa manifestação intertextual e polifônica graças ao alto grau humano de realizar conexões com experiências anteriores empiricamente adquiridas. O autor aponta, desta forma, que a moldura não é capaz de debilitar ou inibir o rico fenômeno humano de realizar analogias com suas experiências sociais, individuais e religiosas. Ressalta, ainda, que o espectador atento e experiente se permite ampliar a observação extraespacial e anacrônico do objeto observado, explorando, assim, o não expresso na obra.

9 Trata-se de uma expressão de origem latina que, segundo o site Dicionário de Latim <www.dicionariodelatim.com.br>, significa "lembra-te que hás de morrer". Depreende-se, assim, que as palavras de Manguel (2001) defendem que narrativas imagísticas podem ser esquecidas. 
O efeito catártico do leitor mencionado por Manguel (2001), ou seja, os arrepios, as indignações, as lágrimas, os sorrisos manifestados no espectador durante o consumo da obra hão de ser reconhecidos nas próprias obras. O autor considera que imagens compartilham o passado, o presente e o futuro do espectador, estes que também são encarregados de emoldurar a pintura observada de acordo com o seu repertório de experiências. Sob essa perspectiva, toda representação artística tende a se tornar uma obra autobiográfica. A imersão profunda do leitor desatento, despreparado ou não treinado "nas águas escuras da incompreensão", como aponta o autor (MANGUEL, 2001, p. 29) podem provocar sentimentos semelhantes, porém motivados por um fator desconfortável: incapacidade de interagir dialogicamente com a obra.

As imagens têm também uma função de autoconhecimento e de autocrítica. Ao citar as palavras de Lacan, Manguel sugere que imagens favorecem que os indivíduos leitores realizem a "identificação alienante", isto é, o modo pelo qual passamos a aprender a nos enxergar e nos autoanalisar a partir das imagens, que passam a desempenhar a função de espelhos externos aos seus leitores. Acrescenta que somos presos fundamentalmente em imagens alheias repletas de outras imagens fraturadas e fortuitas, e que nosso ego se mostra ser uma força inautêntica, funcionando para ocultar a sua essencial falta de unidade.

\section{LITOGRAVURAS DE DEBRET DIALOGADAS COM O CONTO DE MACHADO}

Ambos os autores, como já apontados previamente neste estudo, favoreceram que fossem identificados signos nas obras aqui analisadas que sugerem o engajamento tanto artístico quanto militante coabitando as narrativas.

Os desenhos de Debret são ricos em detalhes de diversas ordens inclusive graças à escola neoclássica na qual se formou artista. A imanência textual da imagem ocasiona ao observador um olhar direto sobre os elementos formais da obra: as cores, a luminosidade, a paisagem, o pano de fundo, as formas, as personagens, a fauna, a flora e diversos objetos e instrumentos.

É efetivamente possível, assim como produtiva, a presente proposta de análise das obras "Feitores corrigindo negros", "Sapataria" e "Jantar" de Debret em íntima consonância com o "Pai contra mãe" de Machado de Assis. Eis alguns tópicos elencados para engatilhar o diálogo entre as obras: o papel socioeconômico do negro escravizado, o indivíduo escravizado como propriedade de outro indivíduo dito livre, o merecimento de corretivos violentos, a infância dos negros filhos de seres humanos escravizados.

Observa-se o prestígio da criança branca diante da filha da escrava assim como se constata "Pai contra mãe", acerca do filho recém-nascido do homem branco, desempregado, que caça negros fugitivos. Portanto, em ambas as narrativas a superioridade tácita e inquestionável no Brasil do século XIX aparece explicitamente nas obras analisadas.

Torna-se oportuno trazer uma reflexão complementar sobre o imaginário dos indivíduos escravizados quanto à sua condição de escravos. Observa-se que a negra capturada prefere o menos pior (servir ao "Candinho") ao muito pior (retornar ao domínio de seu senhor), sem que seja exposto explicitamente a sua liberdade representar efetivamente a sua 
condição mais digna e justa de continuar vivendo. É oportuno, assim, refletir que não basta o negro ser escravo, indivíduo este merecedor e digno de reclusão e garantidor do sucesso da aristocracia e do progresso de um país oligárquico: ele precisa estar convicto que sua condição de escravo é adequada, óbvia e inquestionável graças à concepção elaborada por sua sociedade da qual nem mesmo faz parte efetiva.

As agressões desumanas observadas na obra "Feitores corrigindo negros" (Imagem 1) favorecem uma conexão direta com a seguinte passagem de "Pai contra mãe":

Arminda ia alegando que o senhor era muito mau, e provavelmente a castigaria com açoutes,- cousa que, no estado em que ela estava, seria pior de sentir. Com certeza, ele lhe mandaria dar açoutes. (ASSIS, 1906, p. 10)

O imaginário da "correção" parece se mostrar presente em ambas as obras, legitimando a ideia de propriedade que os ditos proprietários de indivíduos escravizados exerciam sobre estes. A passividade dos pedestres que eventualmente passavam na frente da cena brutal de captura da escrava fugitiva pelo Cândido Neves reitera a conivência da sociedade com a prática escravocrata em "Pai contra mãe".

Houve aqui luta, porque a escrava, gemendo, arrastava-se a si e ao filho. Quem passava ou estava à porta de uma loja, compreendia o que era e naturalmente não acudia. (ASSIS, 1906, p. 10).

A obra "Sapataria" (Imagem 2) tem direta conexão com o exposto acima e, inclusive, com a pressuposição de que "escravo bom é escravo obediente ao seu dono". Chama-se bastante a atenção do leitor dessa imagem quando um olhar atento é direcionado a dois personagens presentes na cena de correção do sapateiro escravizado por seu suposto dono. $\mathrm{O}$ sapateiro sentado logo no canto direito da pintura lança um olhar discreto de canto de olho para o profissional agredido. As expressões faciais discretas daquele homem impossibilitam depreender o que esteja pensando à sua cabeça face à agressão de palmatória: talvez "bem feito!", recriminando o agredido, talvez “que atrocidade!” recriminando o agressor. Por outro lado, a mulher que amamenta o suposto filho observa por trás da porta a agressão, talvez por curiosidade ou talvez para legitimar a correção de indivíduos escravizados com plateia ou em praça pública, como Debret relata também em outras obras. O negro agredido da litografia está ajoelhado, em condição de legítima inferioridade em relação ao seu raivoso senhor que, com uma robusta palmatória, golpeia a mão direita do sapateiro escravizado. O rosto deste indivíduo não é retratado por Debret, sendo oportuno traçar um paralelo com os filhos de Fabiano e da cadela de sua família em "Vidas Secas", de Graciliano Ramos. A identidade do negro agredido é tão insignificante quanto o nome do filho mais velho e do filho mais novo, diferentemente da cadela, batizada como Baleia.

A obra "O Jantar" (Imagem 3) oportuniza duas considerações relevantes a serem expostas: a servidão incondicional e a "refeição" das criancinhas negras. A ausência de alguma criança branca no "Jantar" de Debret colocaria ainda mais em evidência a condição animal das criancinhas negras (cujos prováveis pais não compartilham da refeição, mas estão 
servindo aos seus senhores sentados à mesa) que se alimentam, nuas, no chão graças a um ato singelo e de certa compaixão da senhora branca que veste trajes e adornos sofisticados. Essa imagem desperta no leitor um sentimento de melancolia pela naturalidade com que a cena é apresentada, o que produz um olhar de inconformidade com essa situação. Algo similar pode ser depreendido no foco narrativo do conto "Pai contra mãe" em sua postura distanciada (narrador em terceira pessoa), mas que, a exemplo do quadro, demonstra explicitamente a mais valia do bebê de Candinho, recém-nascido, branco e livre apesar da grande vulnerabilidade financeira de seus pais, em relação ao bebê negro que foi impedido de nascer em virtude da violência sofrida por sua mãe, ou melhor, sofrida por uma negra fugitiva de forma "merecida".

O diálogo entre a arte pictórica e a literatura dos dois artistas atesta que a barbárie do sistema escravocrata não tinha como ser vista como um ato convencional e natural. Essas atrocidades passaram a ser repugnadas justamente na época do boom industrial no hemisfério norte, modificando as relações servil e escrava de produção pela assalariada num clima então recente de liberté, égalité et fraternité difundido com a Revolução Francesa.

As obras analisadas, engajadas artística e subjetivamente, retratam cenários que, na pós-modernidade, tenderiam a causar estranhamento aos seus leitores, legitimando um compromisso artístico de Debret e Machado. Os cenários e as personagens (e suas relações sociais) observados nas obras apresentam narrativas inéditas à estilística sincrônica de sua produção. Assim, romperam com o dogmatismo cultural, religioso e moral sem que a verdade seja nem apreendida nem compreendida em toda sua complexidade, mas problematizada em um grau que transcende a própria materialidade da produção artística. Sob esse prisma, esse compromisso vai ao encontro da definição adorniada da Dialética Negativa:

O conhecimento não possui nenhum dos seus objetos completamente. Ele não deve promover o aparecimento do fantasma de um todo. Assim, a tarefa de uma interpretação filosófica de obras de arte não pode ser produzir a identidade dessas obras com o conceito, consumi-las nesse conceito; não obstante, a obra desdobra-se em sua verdade por meio dessa identidade. Em contrapartida, o que pode ser abarcado, seja como prosseguimento regulado da abstração, seja como aplicação dos conceitos àquilo que é concebido em sua definição, pode ser útil enquanto técnica no sentido mais amplo possível: para uma filosofia que não se subordina, ele é indiferente. Em princípio, ela pode errar constantemente o caminho; e só por isso conquistar algo. O ceticismo e o pragmatismo, por fim ainda na versão extremamente humana desse último, na versão de Dewey, reconheceram esse fato; mas essa ideia precisaria ser introduzida como fermento em uma filosofia enfática e não renunciada em favor de sua prova de validade. Contra o domínio total do método, a filosofia contém, de maneira corretiva, o momento do jogo, que a tradição de sua cientificização gostaria de eliminar dela. (ADORNO, 2009, p. 20)

Portanto, o compromisso artístico de Debret e de Machado alinha-se ao engagement adorniano em detrimento do engagement sartreano: este caracterizado por um propósito 
político-militante de perspectiva panfletária, apesar do engajamento documental incumbido a Debret; enquanto que aquele preza pela constante problematização do mundo sem buscar sua definição diretamente relacionado à Dialética Negativa de Theodor Adorno, em busca de constante problematização do mundo e não em prol de sua definição. Sob esse olhar, o sistema de produção escravocrata legitima a beleza de suas feitorias, que resultaram em altos lucros para a agricultura brasileira beneficiando uma grande minoria, devidamente associadas à barbárie do tratamento desumano do sistema escravagista: o belo e o bárbaro tendem a andar lado a lado (ADORNO, 2009).

As descrições de massacres bélicos e intrigas entre deidades são encontradas nas palavras de Homero e de Ovídio, tratando-se de mitologia greco-romana. Considerando que tais narrativas ecoariam a contemporaneidade da época de sua produção, as telas de Debret não teriam vínculo mitológico, teriam deflagrado o mais alto nível de barbárie em terras brasileiras em pleno século XIX. Brutalidades essas que eram inclusive autorizadas em âmbito jurídico até o Brasil Império, tendo sido atitudes efetivas pelos quatro cantos das terras tropicais dos Orléans e Bragança.

Afinal, Debret somente pintou o que viu e Machado de Assis apenas narrou o conflito entre um pai e uma mãe...

\section{REFERÊNCIAS}

ADORNO. Theodor. Dialética Negativa. Tradução de Marco Antonio Casanova. Rio de Janeiro: Jorge Zahar Ed., 2009.

ANTUNES, Cristina. A Viagem Pitoresca de Debret. Biblioteca Brasiliana Guita e José Mindlin (BBM). São Paulo. s/a. Disponível em:<https://www.bbm.usp.br/node/68>. Acesso em: 15 Maio. 2019.

ASSIS, Machado. Pai contra a mãe. Primeira edição de 1906. Disponível em $:<$ http://machado.mec. gov.br/obra-completa-lista/item/download/24_938f74988ddbf449047 ecc5c5b575985 >. Acesso em: 15 Maio 2019.

Biblioteca Brasiliana Guita e José Mindlin. s/a. Disponível em: <https://digital.bbm.usp.br $>$. Acesso em: 15 Maio 2019.

BRASIL. A Abolição no Parlamento: 65 anos de luta (1823-1888). Vol. 1, 2ª Ed. Brasília: Senado Federal, 2012. Disponível em: <http://www2.senado.leg.br/bdsf/item/id/ 243294>. Acesso em: 15 Maio. 2019.

COSTA, Thiago; DIENER, Pablo. A compreensão do homem na obra de Jean-Baptiste Debret. ANPUH - XXV Simpósio Nacional de História - Fortaleza, 2009. Disponível em:<http://anais.anpuh.org/wpcontent/uploads/mp/pdf/ANPUH.S25.0958.pdf>. Acesso em: 15 Maio. 2019.

DEBRET, Jean-Baptiste. Voyage pittoresque et historique au Brésil : Séjour d’un Artiste Français au 
Brésil. Tome Premier. Paris : Firmin Didot Frères, 1834.

Voyage pittoresque et historique au Brésil : Séjour d’un Artiste Français au Brésil. Tome Deuxième. Paris : Firmin Didot Frères, 1835.

Voyage pittoresque et historique au Brésil : Séjour d’un Artiste Français au Brésil. Tome Troisième. Paris: Firmin Didot Frères, 1835.

DIGNAT, Alban. L'esclavage en Occident. Herodote.net, 2018. Disponível em:

$<$ https://www.herodote.net/Esclavage_une_memoire_mal_orientee-article-1723.php >. Acesso em: 15 Maio 2019.

ITAÚ. Debret. In. : Enciclopédia Itaú Cultural. São Paulo: Itaú Cultural, 2016. Disponível em: $<$ http://enciclopedia.itaucultural.org.br/pessoa18749/debret>. Acesso em: 15 Maio 2019.

MANGUEL, Alberto. Lendo imagens: uma história de amor e ódio. Tradução de Rubem Figueiredo et alii. São Paulo: Companhia das Letras, 2001.

MARINHO, Fernando. Machado de Assis. Brasil Escola. Disponível em <https://brasilescola.uol.com. br/literatura/biografia-machado-assis.htm>. Acesso em 15 de maio de 2019.

SAINT-HILAIRE, Auguste. Viagem ao Rio Grande do Sul. Tradução de Adroaldo Mesquita da Costa. Brasília: Senado Federal, Conselho Editorial, 2002. 
